\title{
An ethical reflection on dnug use in eSport
}

\author{
Sungjoo Park ${ }^{1}$, Dayoun Lim¹, \& Jinhee Kim²* \\ ${ }^{1}$ Kookmin University \& ${ }^{2}$ Andong National University
}

[Purpose] Highly popular these days, eSport is inviting increasing scholarly attention and research. Scholarly work on eSport, however, remains focused on whether eSport is a "real" sport, that is, its sporting qualities and status, excluding ethical issues. This paper analyzes ethical issues about cognitive enhancement drugs often associated with eSport in order to suggest guidelines for resolving these issues. [Methods] First, environmental features of eSport are examined to find out types of cheating in eSport, as well as the ways eSport athletes are exposed to drugs. Next, ethical issues of cognitive enhancement drug use and why they are important are discussed, drawing upon multiple scholars. Last, this paper argues that the ban on drug use conventionally implemented in sport is not appropriate to eSport due to the characteristics of eSport. The paper concludes with possible future approaches to this issue. [Results] The ban lists administered by ESIC and WADA would not work for the need of eSport athletes and even run a risk of stunting the growth of eSport industries. It is thus important to think up an appropriate drug-related policy for eSport. Preemptive education for eSport athletes is also required to promote the ethical consciousness and judgment regarding drug use. [Conclusion] Insofar as eSport's huge popularity leads to the increased status of eSport athletes, thereby exerting much influence on young people, ethical questions about eSport, drug use in particular, need to be urgently discussed for the sake of eSport's wholesome development.

Key words: eSport, cognitive enhancement drug, cheating, ethical issues, WADA

\section{서 론}

우리나라 초등학생의 장래희망으로 10 년 넘게 상위 10 위 안에 자리 잡고 있는 직업이 있다. 바로 프로게이머 다. 교육부와 한국직업능력개발원이 조사하여 발표하는 '초중등 진로교육 현황'에서 프로게이머는 초등학생 희망 직업에서 2007년 10위, 2017년 8위, 2018년 9위, 2019 년 6위를 기록했다(Kim, 2019.08.17). 미국 시장조사 전문 기관인 〈Newzoo〉는 '2020 세계 e스포츠 시장 보고

논문 투고일 : 2020. 04. 22.

논문 수정일 : 2020. 05. 18.

게재 확정일 : 2020. 05. 31.

* 교신저자 : 김진희 (jkim@anu.ac.kr).
서'를 통해 e스포츠 시장 규모가 2020년 11억 달러(한화 약 1 조4천억 원) 수준에 달할 것으로 전망했다 (Rietkert, 2020.01.07). 세계 최고 인기 e스포츠 구단 인 'T1'을 보유하고 있는 SK텔레콤은 2022년까지 e스포 츠 시장 규모가 3 조5000억 원에 달할 것으로 내다봤다 (Jang, 2020.03.09). 미국의 유명 증권회사인 골드만삭 스 또한 글로벌 e스포츠 산업은 미국, 아시아, 유럽을 중 심으로 2018년 8억6천900만 달러(한화 약 1조700억 원)에서 2022년 29억6천300만 달러(한화 약 3조6천 700 억 원) 규모로 매해 $35 \%$ 이상의 고성장이 예상된다 고 밝혔다(Kim, 2019.10.11). 지난 2018년 자카르타. 팔렘방 아시안 게임에선 리그 오브 레전드 $(\mathrm{LoL})$ 와 히스 스톤 등 6 개의 게임이 시범종목으로 채택될 정도로 $\mathrm{e}$ 스포 
츠의 위상은 높아졌다(Jang, 2020.03.09). 국내에서는 2007년 처음으로 e스포츠학과를 개설한 전남과학대학교 를 비롯해 청강문화산업대, 가천대 등 여러 대학들이 $\mathrm{e}$ 스 포츠 관련 학과도 운영하고 있다(No, 2019.12.05).

도시화와 IT기반 시설, 특히 비디오 스트리밍 기술과 인터넷 연결 속도가 발달함에 따라 모바일 게임을 중심으 로 증가하는 $\mathrm{e}$ 스포츠 시청자 수는 $\mathrm{e}$ 스포츠에 대한 높은 관심을 방증한다. 가장 인기가 높은 $\mathrm{e}$ 스포츠 종목은 리그 오브 레전드 $(\mathrm{LoL})$ 라는 판타지 전투 전략 게임으로, 2009년 데뷔 이래 LoL은 소수의 데스크탑 컴퓨터 속 전 사들에서 대규모의 사회문화 현상으로 발전했다. 지난해 '2019 리그 오브 레전드 월드챔피언십(롤드컵)'은 분당 평균 시청자 2,180 만 명을 기록했었다. 이는 인기 프로스 포츠인 $\mathrm{MLB}$ 월드시리즈나 $\mathrm{NBA}$ 챔피언 결정전의 시청 자 수를 넘어서는 수치이다(Holden, Kaburakis, \& Tweedie, 2019). 〈Newzoo〉는 2020년 전 세계 e스포츠 시청자 수를 4억9,500만 명으로 추산했고, 이는 2019년 4억4,300만 명보다 $11.7 \%$ 증가한 수치이다 $(\mathrm{Kim}$, 2020.03.06).

2000년대 초반 이후 빠른 성장과 큰 성공을 거둔 사회 대중적 현상으로서 $\mathrm{e}$ 스포츠는 비록 축구, 농구, 야구, 배 구처럼 전통적인 스포츠로서 주류 사회의 수용에 이르지 는 못했음에도 불구하고, $\mathrm{e}$ 스포츠 또한 스포츠에서 발생 하는 유사한 윤리적 해악에 물들어 있다. 인기 프로스포 츠뿐 아니라 다른 대부분의 스포츠처럼 $\mathrm{e}$ 스포츠 역시 거 대한 도박 산업에 관련되어 있다(Holden \& Ehrlich, 2017). 도박 산업은 불법도박이나 승부조작 사건으로 이 어져 $\mathrm{e}$ 스포츠선수가 법적으로 구속되고 리그 자체가 폐 지되는 등 여러 심각한 문제를 야기해왔다(Holden, Kaburakis, \& Rodenberg, 2017). 주로 e스포츠계의 승 부조작 사건이 언론이나 대중의 큰 주목을 받아온데 비해, $\mathrm{e}$ 스포츠선수의 약물복용 문제는 사람들의 관심에서 벗어 나 있는 듯하다. e스포츠선수의 약물복용은 아주 흔하고 널리 퍼져 있는 일인데, 어떤 선수는 거의 모든 e스포츠 선 수들이 약물을 복용하고 있다고 말하기도 한다(Holden, Kaburakis, \& Tweedie, 2019). 사실 올림픽 스포츠에서 발생하고 있는 경기력 향상약물 (performance-enhancing drugs, PED) 복용의 문제, 특히 아나볼릭 스테로이드 (anabolic steroid)와 같은 근육강화제 사용의 문제와 $\mathrm{e}$
스포츠선수들이 집중력이나 인지능력 향상을 위해 복용 하는 리탈린(Ritalin)이나 애더럴(Adderall) 같은 향정 신성 약물사용 문제는 경기력 향상, 즉 도핑이라는 측면 에서는 크게 다르지 않다. 하지만 $\mathrm{e}$ 스포츠 선수들이 사용 하는 각성, 집중력, 주의력, 기억력 등과 관련 있는 약물 사용은 문제의식과 심각성 측면에서 가볍게 여기는 분위 기가 조성되어 있다(Holden, Kaburakis, \& Tweedie, 2019). 이는 리탈린(Ritalin), 모다피닐(Modafinil), 애 더럴(Adderall)과 같은 약물이 처방전만 있으면 쉽게 얻 을 수 있다는 점을 고려할 때 더욱 우려스러운 것이다.

기면증(대낮에 참을 수 없이 졸리고 수면에 빠지는 병 증) 치료제로 개발된 모다피닐(modafinil)이나 주의력 결핍 장애(Attention deficit Disorder, $\mathrm{ADD}$ )와 주의력 결핍 과잉행동 장애(Attention Deficit Hyperactivity Disorder, $\mathrm{ADHD}$ ) 치료제인 흔히 리탈린이라는 제품명 으로 불리는 메틸페니데이트(Methylphenidate)와 애더 럴은 질병 치료를 목적으로 개발된 의약품이다. 그러나 정상적인 뇌 기능을 향상시키는 효과가 알려짐으로써 원 래 목적과는 다르게 이미 서구 사회 학생들 사이에서 각 성제로 널리 유통되고 있는 실정이다. 실제로 미국 학생 들 사이에서 애더럴은 '공부 잘하는 약'으로 통하며, 이 약 을 얻을 목적으로 $\mathrm{ADD} / \mathrm{ADHD}$ 판정을 받는 경우도 있다 (Holden, Kaburakis, \& Tweedie, 2019). 국내에서도 효능 탓에 한때 일부 학부모 사이에 큰 인기를 끌었고, 국 내에서는 처방이 금지된 애더럴을 유명 걸그룹 멤버 중 한 명이 국제우편으로 들여와 사회적 이슈가 되기도 했다 (Park, 2019.10.01). 한때 학생들 사이에 시험공부를 위해 자양강장제나 캔커피에 카페인이 함유된 '레드불'이 나 ‘핫식스' 같은 에너지음료를 섞은 일명 '붕붕드링크'도 유행하였다(Lee \& Choi, 2013). 2016년 건강보험심사 평가원의 자료에 따르면, 고등학생 대상의 메틸페니데이 트 처방건수가 점점 증가하고 있고, 특히 고등학교 3학년 인 18세에 대한 처방이 대학수학능력시험을 앞둔 10 월에 급증한다고 보고하였다(Kim, 2018).

모다피닐은 군인, 연구원, 학생, 기업가들이 잠을 자지 않고 깨어 있는 시간을 증가시키기 위해 사용하는 대표적 인 약물 중의 하나이다(Yang, 2015.09.04; Chu, 2014). 일부 스포츠선수들이 자신의 운동 능력 혹은 경 기력을 향상시키기 위해 아나볼릭 스테로이드를 복용하 
는 것처럼 학생, 연구원, 직장인들이 인지능력 증진을 목 적으로 신경 향상 약물을 찾고 있다. 그렇다면 중요한 시 험을 성공적으로 치르기 위해 커피를 수십 잔씩 마시면서 밤늦도록 공부하는 학생과 기면증 치료제인 모다피닐을 복용하면서 공부하는 학생 간에는 어떤 윤리적 차이가 있 는 것일까? 국가공무원 공채 시험 경쟁에서 성공하기 위 해 모다피닐을 복용하는 수험생과 $\mathrm{e}$ 스포츠선수로서 치열 한 경쟁에서 살아남기 위해 모다피닐을 복용하는 것에는 윤리적으로 어떤 차이가 있는 것일까? 전자는 허용되고, 후자는 금지되어야 하는 것일까? 그렇다면 그 근거는 무 엇이고 기준은 어떻게 정해야 하는 것일까?

현재 $\mathrm{e}$ 스포츠는 엄청난 인기를 구가하고 있고 $\mathrm{e}$ 스포츠 에 관한 학계의 관심과 연구도 활발해지고 있다. 하지만 현재 $\mathrm{e}$ 스포츠에 대한 학계의 연구는 $\mathrm{e}$ 스포츠가 정말 스포 츠인지, 즉 스포츠로서 갖는 자질과 지위에 관한 논의에 집중되어 있고 $\mathrm{e}$ 스포츠에서 발생하는 여러 윤리적 문제 에 관한 학술적 조사나 연구는 거의 없는 실정이다. 이러 한 학문적 공백을 메꾸기 위해 본 연구는 e스포츠가 직면 한 인지 향상 약물 (cognitive enhancement drugs) 복용 문제의 윤리적 쟁점을 분석함으로써 $\mathrm{e}$ 스포츠계의 약물복용 문제 해결을 위한 바람직한 방향성을 제시하고자 한다.

이러한 연구목적을 달성하기 위해, 먼저 $\mathrm{e}$ 스포츠의 환 경적 특징을 살펴봄으로써 $\mathrm{e}$ 스포츠계 부정행위의 양상과 선수들이 약물복용 문제에 노출되는 배경을 파악하고자 한다. 다음으로 e스포츠선수의 인지 향상 약물 복용문제 에 관해 어떤 윤리적 쟁점이 존재하고, 왜 그것이 쟁점이 되는지를 여러 학자들의 입장을 통해 고찰하고자 한다. 끝으로 $\mathrm{e}$ 스포츠의 환경적 특성을 고려할 때 전통적 스포 츠로부터 차용한 약물복용 금지 정책이 왜 $\mathrm{e}$ 스포츠에 부 적합한지를 지적하며, 약물복용 문제에 대처하기 위한 $\mathrm{e}$ 스포츠계의 바람직한 접근방안을 제시하고자 한다. $\mathrm{e}$ 스 포츠가 주로 젊은 층을 대상으로 세계적으로 인기를 끌고 있고, 그로 인해 프로 $\mathrm{e}$ 스포츠 선수의 위상과 지위도 높 아지면서 청소년에게 미치는 파급력과 영향력을 감안할 때, $\mathrm{e}$ 스포츠의 윤리적 문제, 특히 약물복용에 관한 문제 는 시급하고 시의적인 논의이며 $\mathrm{e}$ 스포츠의 확산과 건강 한 발전에도 함의하는 바가 클 것이다.

\section{$\mathrm{e}$ 스포츠 환경과 부정행위}

현재 e스포츠가 경쟁스포츠의 형태로 전 세계적으로 큰 인기를 끌고 있지만, $\mathrm{e}$ 스포츠 역시 다양한 부정행위들 을 일으키고 있다. 규칙은 스포츠를 구성하는 핵심 요소 이다. 즉 규칙들이 스포츠를 특정한 형태의 경쟁 활동으 로 구성한다. 어떤 행위가 스포츠행위로 인정받으려면 그 스포츠가 가진 규칙, 즉 구성적 규칙 (constitutive rule) 과 규제적 규칙(regulative rule)을 준수해야 한다. 그렇 지 않을 경우, 공정성의 문제가 제기되고 부정행위로 간 주될 수 있다(Feezell, 2013; Loland, 2002; Parry, 2019; Suits, 2018). 다른 스포츠의 경우와 마찬가지로 $\mathrm{e}$ 스포츠에서도 페어플레이 원칙을 중요시한다. 물론 $\mathrm{e}$ 스 포츠의 환경적 특성 때문에 참가자의 부정행위나 의도적 규칙위반이 전통적 스포츠와 다른 양상으로 나타나는 부 분도 있다. 예를 들면, 아마추어 게임에서는 온라인 기반 이기 때문에 누구나, 언제 어디서나 경기에 참여할 수 있 다. 이것은 심각한 문제를 수반하는데, 누구나 아무 때나 게임에서 로그아웃 해버릴 수 있기 때문이다. 이러면 팀 플레이가 심하게 위협받으며 페어플레이 정신에도 위배 된다. 이러한 위험을 최소화하기 위해, 그리고 디지털 환 경으로 인해 모든 퍼포먼스가 정확하게 모니터링 될 수 있기 때문에, 미완성된 게임을 두고 일방적으로 떠나는 것에는 벌금이 부과된다(Llorens, 2017). 채팅이나 라이 브 경기에서 팀원이나 상대편을 말로 괴롭히는 것, 혹은 약한 상대에게 불필요하게 굴욕적인 공격을 하는 것과 같 은 매너에 어긋나는 행동도 페어플레이에 위배되며 벌금 이 부과된다(Hemphill, 2005). 온라인 게임 모드에서는 모든 채팅이 기록되므로 이러한 행동을 모니터링 할 수 있다. 온라인이 아닌 지역 네트워크(LAN)에서 열리는 프로 경쟁에서는 심판이 제재를 내린다.

당연히 부정행위나 의도적 규칙위반은 e스포츠의 페어 플레이 원칙에 어긋나는 관행이다. 그러나 $\mathrm{e}$ 스포츠의 디 지털 성격 때문에 경기 규칙은 코드에 프로그래밍이 되어 있고, 따라서 부정행위나 의도적 규칙위반이 가능한지 여 부에 대해 질문할 수 있다. 즉 $\mathrm{e}$ 스포츠의 부정행위는 게 임의 코드에 의해 제한되기에, 이것은 곧 경기자가 프로 그래밍 되어 있지 않아 허용되지 않는 움직임을 아예 수 행할 수 없음을 의미하기 때문이다(Llorens, 2017). 이 
런 이유로 의도적인 규칙위반을 저지르기는 어렵지만 그 래도 게임 안팎에서 몇몇 형태의 부정행위들이 저질러지 고 있다. 게임 밖 부정행위의 예로는 LAN 경쟁에서 게임 장치 문제로 게임이 일시 중단되었을 때 게이머가 서로 이야기를 나누는 경우다(Hemphill, 2005). 그러나 가장 흔한 부정행위는 게임 안 부정행위인 DDOS 공격과 스크 립트다. 첫 번째 것은 상대방 서버를 공격해 트래픽으로 포화시키고 접속 지연을 발생시키는 것이고, 두 번째는 사용자의 게임 플랫폼 및 캐릭터의 퍼포먼스 향상을 위한 프로그램을 사용하는 것이다(Llorens, 2017). 이 경우 게이머의 계정 금지라는 최고 벌칙이 적용된다.

이제는 $\mathrm{e}$ 스포츠를 단순히 시청만 하는 것이 아니라, 아 마추어 게이머가 실제로 $\mathrm{e}$ 스포츠에 참여하는 것이 휠씬 더 쉬워졌다. 2014년 6월에 시작된 지피니티 (Gfinity.net)는 온라인 e스포츠 대회를 매일 제공하고, 매달 거의 5 만 달러의 상금을 준다(Jenny et al., 2017). 캘리포니아 산타 모니카의 비디오 게임 출판사 라이엇 게 임즈(Riot Games)는 수백 명의 프로 게이머들에게 월급 을 주며 함께 LoL을 생산하는데, 이 중 대부분은 엘리트 수준 경쟁력을 유지하기 위해 하루 최대 14 시간을 연습 한다(Jenny et al., 2017). LoL에는 전 세계적으로 6천 7백만 명의 정기적인 게임 플레이어가 있고, 이들이 게임 을 하며 쓰는 돈은 1 억2천2백만 달러(한화 약 1천5백억 원)에 이른다(Abanazir, 2019). 한국은 e스포츠의 종주 국이라 할 수 있으며 1999년 국내에서 '프로게이머 코리 아오픈 $(\mathrm{PKO})^{\prime}$ 이 개최된 것이 세계 최초다. 라이엇 게임 즈에 따르면, 국내에서 LoL을 하는 인원은 약 300만 명 정도로 추산하고 있다(Wingfield, 2104). SK텔레콤의 경우 이미 유명 프로게임단 'T1'을 운영 중이다. 2004년 에 'T1 스타크래프트' 팀을 시작으로, T1은 한국 e스포츠 분야에서 가장 많은 우승과 스타 플레이어들을 배출한 명 문 구단으로 꼽힌다.

프로 e스포츠선수는 20세 전후로 전성기를 맞는다. 한 국콘텐츠진흥원의 발표에 따르면 2019년 기준 국내 e스 포츠 프로선수들의 숫자는 약 420 명이고, 이들의 평균 연령은 20.2세, 연습생은 17.4세다(Lee, 2020.03.12). 재능 있는 선수들은 보통 중학교 때 발탁되어 육성군 활 동에 들어가고, 고등학교 때부터 프로 생활을 시작한다. 전체 프로 선수 중 33퍼센트에 해당하는 선수들이 연령
대가 17세에서 19세이다(Lee, 2020.03.12). 이처럼 많 은 선수들이 미성년자이고, 그렇다보니 부족한 사회 경험 과 판단력 미숙으로 인해 불공정 계약이나 비리, 사기 행 위 등의 부정행위에 취약한 상황에 놓여있다. '2018 e스 포츠 실태조사'에 따르면, 프로 $\mathrm{e}$ 스포츠선수의 평균 연봉 은 1억7600만 원에 달한다(Lee, 2019.06.29). 하지만 이는 소수의 프로선수에게만 주어지는 보상이며 아마추 어에서는 $5.4 \%$ 만이 연 200만 400만 원 이상의 소득을 올리고, $35.7 \%$ 가 200 만원 미만이며, $58.9 \%$ 는 한 해 소 득이 전혀 없었다(Lee, 2019.06.29). 대부분 고등학생 때 데뷔를 하는 어린 선수들은 프로선수가 되면 엄청난 돈을 벌고, 언론의 스포트라이트와 팬들의 환호를 받을 수 있다는 희망에 부풀어 때론 구단의 부당한 계약이나 지시에 수긍하고, 그것이 부당하거나 잘못된 것인지 조차 도 인식하지 못하는 경우가 많다(Lee, 2020.03.12.).

$\mathrm{e}$ 스포츠 선수들 역시 우리가 흔히 알고 있는 일반적인 스포츠의 선수들처럼 경기력에 대한 엄청난 압박을 받는 다. 문제는 스타 축구선수를 꿈꾸는 어린 선수들과 달리, 프로 e스포츠 선수를 꿈꾸는 어린 선수들은 일주일 내내 하루 열 두 시간씩 컴퓨터 앞에서 보내기도 한다 (Holden, Kaburakis, \& Tweedie, 2019). 어떤 선수들 은 전혀 잠을 자지도 않고 24 시간 게임만 하는 경우도 있 다. 부족한 수면시간, 일반적이지 않은 생활패턴과 식단, 그리고 특정 신체부위만 사용하는 빠른 반복 행동은 아직 성장기에 있는 어린 선수들에게 다양한 건강 문제를 발생 시킨다. 미국 뉴욕 기술연구소 e스포츠의학 센터에 따르 면, 오랜 시간 동안 게임을 하는 선수들은 대부분 건강상 의 부작용에 대해 인지하고 있지 않으며 과도한 반복 동 작은 손목, 허리, 목 부상으로 이어질 수 있다 $(\mathrm{Lim}$, 2019.10.02) . 2019년 뉴욕 공과대학의 연구에서 밝혀진 $\mathrm{e}$ 스포츠 선수들에게 자주 발생하는 질병은 눈의 피로, 목 과 허리의 통증, 손목과 손의 통증 등이며, 그 원인으로는 장시간 동안 고정된 자세로 지속적으로 연습하는 환경이 다(Lim, 2019.10.02). 다른 전통적인 스포츠와 마찬가 지로, $\mathrm{e}$ 스포츠에서도 모든 선수가 자의적으로 은퇴하는 것은 아니다. e스포츠선수들 또한 연습환경, 생활습관, 장시간의 훈련으로 인한 건강상의 이유로 이른 시기에 은 퇴하는 경우도 많다(Hemphill, 2005). 이처럼 e스포츠 선수는 대부분 어린 나이에 많은 돈을 벌고, $6 \sim 7$ 년의 짧 
은 기간의 전성기를 누린 후 은퇴를 준비해야 하는 선수 들은 금전적 유혹과 승리에 대한 압박에서 벗어나기 힘든 상황에 놓여있다.

$\mathrm{e}$ 스포츠선수들은 다른 일반적인 스포츠의 선수들과 달 리 대개 성년에 이르기 전에 프로가 된다. $\mathrm{e}$ 스포츠선수들 은 어린 나이에 프로선수로 활동하며 엄청난 돈을 벌게 되지만, 평균 은퇴 예상 나이는 26.1세로 매우 이른 편이 다(No, 2019.12.05). 그 어떤 스포츠선수 경력도 20대 중반이면 대개 끝나버리는 e스포츠선수 경력만큼 빨리 연소되지 않는다. 프로 e스포츠팀의 특징 중 하나는 팀이 1 주일 내내 24시간 한정된 공간에 고립되어 있다는 점이 다. 비록 의자와 마우스, 키보드가 인체공학적으로 향상 되기는 했어도 끝없는 시간동안 화면에 집중해야만 한다 는 도전은 여전히 남아있다. 프로 $\mathrm{e}$ 스포츠선수들이 직면 한 주요 도전 중 하나는 바로 생존의 문제이다. 사실상 프 로 $\mathrm{e}$ 스포츠는 상위 몇 퍼센트의 선수들에게만 돈이 집중 되어 있는 구조이다. 이러한 상황 속에서 선수들에게 건 강과 윤리의 문제는 우선시되지 않는다. 프로 $\mathrm{e}$ 스포츠 세 계의 치열한 경쟁에 살아남기 위해 선수들에게는 피로를 덜 느끼는 가운데 각성도를 유지하고, 주의력과 집중력을 높이는 것이 그들의 성공에 있어 무척 중요하다. 그러한 효과가 있는 약물이라면 건강상의 위험을 감수하고라도 자신의 경쟁력 향상과 성공을 위해 마다하지 않는다.

\section{$\mathrm{e}$ 스포츠선수의 약물복용에 관한 윤리적 쟁점과 논의}

스포츠에서 부정행위는 스포츠의 시작부터 함께 있어 왔다고 해도 과언은 아니다. 그 역사는 최소 그리스 올림 피아에서 열렸던 올림픽 경기장으로까지 거슬러 올라간 다. 상대편을 매수하는 등의 부정행위가 초기 올림픽 경 기 때부터 금지된 것이었던 반면, 약물복용은 고대 그리 스 도시 국가들에서 제도화되어 있었고 근대까지 부정행 위로 간주되지도 않았다(Chrysopoulos, 2016; Yesalis \& Bahrke, 2002). 1929년 암페타민(amphetamine) 개발과 더불어 20 세기 중반에 강력한 각성제, 흥분제 등 의 복용이 스포츠계와 사회 전반에 퍼지게 되었다. 암페
타민 복용이 2 차 대전 중 미국과 그 밖의 지역에서 늘어 났는데, 우울증 치료제로 약국에서 쉽게 구매할 수 있었 기 때문이다(Rasmussen, 2008). 이 기간 동안 미국은 영국, 독일, 일본군과 마찬가지로 비행사들에게 흥분제 를 공급했다. 다양한 병의 '만병통치약'으로 암페타민이 나 다른 향정신제를 처방하는 관행은 차차 정부의 정밀조 사 대상이 되었고 결국 정부 규제를 받게 되었다 (Holden, Kaburakis, \& Tweedie, 2019). Rasmussen (2008)에 따르면, 약한 우울증 치료나 의료 감독을 받으 며 진행하는 체중 감소처럼 합법적 의료 목적으로 쓰이는 암페타민은 쉽게 구할 수 있듯, 최근 리탈린(메틸페니데 이트)이나 애더럴(암페타민)처럼 주의력 결핍 및 과잉 행 동장애 치료약이 구하기 쉬워지고 있다. 이렇게 사회 전 반적으로 향정신제 약물을 구하기 쉬워지는 것은 e스포 츠계에서 약물 규제가 어려워짐을 뜻한다.

2008년 〈네이쳐〉지의 조사에 따르면, 미국의 경우 다 섯 명의 응답자중 한 명이 리탈린, 모다피닐, 혹은 베타 차단제 (beta-blocker, 협심증 및 고혈압 치료제) 같은 각 성제/안정제를 치료 목적과는 관계없는 생산성 촉진을 위해 사용한 적이 있다고 답했다(Maher, 2008). Racine 과 Forlini(2010)에 따르면, 처방약을 인가받지 않거나 ‘비의학적 용도'로 쓰는 것이 미국에 만연하고 있는데, 특 히 메틸페니데이트나 애더럴 같은 향정신제는 젊은이들 사이에서는 약 10-30퍼센트가 비의학적 용도로 복용된 다고 한다. 이러한 약물이 스포츠계에서는 엄격히 금지되 어 있지만, 스포츠계 밖의 사람들, 예를 들어 학자, 연구 원, 군인, 음악가 등이 집중력 향상이나 긴장 완화의 목적 으로 복용하는 것에 관해서는 뚜렷한 윤리적 평가는 없다 (Racine \& Forlini, 2010). 일반 전문인들이 자신들의 퍼포먼스 향상을 위해 이러한 향정신제를 사용하는 것과 스포츠에서 성공하려는 선수들이 이러한 향상 약물을 사 용하는 것에 대해 다른 잣대를 들이대는 근거가 모호하 다. 예를 들면, 콩쿠르와 같은 음악 경연대회에서 참가자 가 불안과 긴장감을 해소하여 경쟁에 우위를 차지하기 위 해 베타 차단제와 같은 약물을 복용하는 것에는 어떠한 제재도 윤리적 비난도 없다.

스포츠선수들이 스테로이드(근육강화제)를 쓰는 것이 의학적으로는 불필요하다. 하지만 향정신제 같은 경우에 는 의학적 목적과 향상의 목적에 대한 구별이 불명확하 
다. 예를 들어, 애더럴은 많은 이들에게, 특히 청소년에게 의학적으로 절실히 필요한 도움을 제공하는 약물이다. 주 의력 결핍 장애 $(\mathrm{ADD})$ 나 주의력 결핍 과잉행동 장애 $(\mathrm{ADHD})$ 가 있어 애더럴을 복용하는 청소년들에게 스포 츠를 못하게 할 수는 없다. 즉 개인의 의학적 건강 상태가 스포츠에 참여할 수 있는 권한을 제한해서는 안 될 것이 다. 의학적으로 적절한 치료가 필요한 운동선수 또한 스 포츠에 참여하는 데 제약이 있어서는 안 되기에 치료목적 사용면책(Therapeutic Use Exemption, TUE)이라는 제도가 있다. 예를 들어, 미국 메이저리그 야구선수들도 $\mathrm{ADD}$ 혹은 $\mathrm{ADHD}$ 진단을 받게 되면 일반인과 마찬가지로 애더럴을 복용할 수 있는데, 이를 위해서는 치료목적 사 용면책(TUE)을 승인받아야 한다. 2016년 시즌 메이저 리그 야구에서 118 명의 선수에게 TUE가 발급되었다 (Rodenberg \& Holden, 2017). 또한 2001년 미국 대법 원 판결에 따라 미국프로골프협회(PGA)는 의학적으로 조건이 갖춰진 선수들에게 카트 사용도 허가했다 (Holden, Kaburakis, \& Tweedie, 2019). 이렇게 의학 적으로 필요한 면책을 통해 개인의 건강 상태와 상관없이 누구나 그들이 좋아하는 스포츠를 지속할 수 있게 하는 것은 스포츠의 접근권 측면에서 매우 중요하다.

대한소아청소년정신의학회의 발표에 따르면, 국내 $\mathrm{ADD} / \mathrm{ADHD}$ 잠재 환자 수는 소아 36 만 명, 청소년 20만 명, 성인 150만 명으로 추산된다(Min, 2018.04.10). e 스포츠에서 인지 향상 약물에 대한 논의가 중요한 이유는 오늘날 비디오 게임과 $\mathrm{e}$ 스포츠라는 청소년들이 가장 좋 아하는 취미와 향정신제 약물간의 독특한 관계 때문이다. 그러한 관계 때문에 다른 스포츠 종목에서와 달리 규제의 어려움이 발생한다. 현재 상당수 젊은이들이 메틸페니데 이트나 모다피닐, 피라세탐 같은 약물을 처방받거나 뇌 기능 개선을 목적으로 처방전 없이 온라인을 통해 구입하 고 있다. 그리고 $\mathrm{e}$ 스포츠를 즐기고 참여하는 젊은이들의 수도 급속히 많아지고 있다. e스포츠의 경쟁성, 점점 커 지는 상업적 가치와 금전적 보상, 그리고 다른 전통적인 스포츠처럼 사회적으로 받아들여지고 싶은 욕구 등이 모 다피닐이나 메틸페니데이트 같은 인지 향상 약물에 대한 유혹을 야기하며 이러한 약물의 허용과 금지에 대한 매우 어려운 논쟁을 $\mathrm{e}$ 스포츠계가 겪고 있다.

세계반도핑기구(World Anti-Doping Agency,
$\mathrm{WADA}$ )는 약물복용에 관한 규정을 매해 업데이트 하고 있다. WADA는 선수들 건강을 위협하는 경우, 선수의 경 기력을 강화하는 경우, 스포츠정신을 훼손하는 경우, 이 3 가지 경우 중 두 가지에 해당되는 약물은 공식적인 금지 목록으로 등재하여 제지하고 있다(Engelberg \& Skinner, 2016). 하지만 WADA의 금지 목록에 있는 약 물일지라도 적법하게 의학적 필요에 의해 사용하는 선수 를 배제할 만큼 엄격하지는 않다. 치료목적 사용면책 (TUE) 제도에 의해, 선수들은 $\mathrm{WADA}$ 에서 요구하는 서 류를 잘 갖춰 신청하면 금지된 약물이라도 복용을 허락받 을 수 있다. Overbye와 Wagner(2013)는 적법한 의학적 필요에 의한 복용과 퍼포먼스 향상을 위한 복용 사이의 기준이 매우 불명확하다며 치료목적 사용면책 제도의 불 완전함을 지적한다. 다른 많은 학자들도 약물금지 프로토 콜을 철저히 지키면서 동시에 TUE를 허용하는 시스템을 시행하는 것의 어려움을 지적한다(Holden, Kaburakis, \& Tweedie, 2019; Overbye \& Wagner, 2013; Tcholl $\&$ Dvorak, 2012). 철저함과 허용 사이의 균형을 유지하 는 것은 특히 e스포츠에서 신경 향상 약물복용 규제와 관 련해 더욱 어렵다.

실제로 메틸페니데이트, 암페타민, 모다피닐, 피라세탐 과 같은 약리학적 신경 향상 물질들은 사람을 해치려고 만 든 약물이 아니라 사람들을 치료하기 위해 개발된 치료제 이다. 당연히 적절하게 복용한다면 해로움(harm) 보다 이로움(benefit)을 제공하는 약물들이고, 인지적 향상, 즉 주의력, 집중력, 뇌 기능 증진에 효능이 있다고 알려진 치 료제다. $\mathrm{e}$ 스포츠의 약물복용 문제에 있어 중요한 쟁점 중 에 하나는 바로 치료(therapy)와 향상(enhancement)의 구분이다. $\operatorname{Kim}(2017)$ 의 구분에 의하면, 치료는 손상된 기능과 능력을 정상 범주로 회복시키는 의료 차원의 개입 을 의미하고, 향상은 인위적인 개입을 통해 정상적인 기 능과 능력을 한층 더 높이는 것을 말한다. 즉 다친 부위를 치료하여 원래의 상태로 건강을 회복시키는 것은 문제될 것이 없지만, 치료와 더불어 정상상태를 넘어서는 것은 윤리적으로 문제가 된다는 것이다. 하지만 문제는 치료와 향상을 어떻게 명확히 구분하느냐는 것이다.

이러한 점에서 Loland(2018) 또한 선수의 건강에 해 롭다는 이유로 약물을 금지하는 것은 그 근거가 불충분하 다고 주장한다. 신경 향상 약물이 건강상에 위협이 있다 
고 하더라도 개인의 건강에 대한 결정은 바로 개인 자신 에게 달려 있는 것이 아니냐는 주장 또한 약물복용 문제 에 있어 주된 쟁점이다. Brown(2009)은 운동선수는 개 인의 자기 신체소유권을 가지고 있으며, 위험성에 대해서 도 인지하고 있기 때문에 스스로 약물을 복용하겠다는 선 택을 제지하는 것은 개인의 자율권을 침해하는 것이라고 주장한다. 즉 타인에게 해를 끼치지 않는다면, 자신의 건 강상 위험을 감수하고 향상 약물을 복용하는 것을 제지지 해서는 안 된다는 것이다. 이는 인간의 자율성과 관련되 는 쟁점이다. 인간은 스스로 결정하고 판단할 수 있는 자 율성이 있기에 개인이 인지 향상 약물을 이용할 것인지의 여부는 스스로 자유롭게 결정해야 한다는 것이다 $(\mathrm{Chu}$, 2018).

많은 프로 그리고 아마추어 $\mathrm{e}$ 스포츠 선수들은 다른 종 목의 선수들처럼 자신들의 경기력을 향상시키는 다양한 방법을 찾는 데 몰두해왔다. 그리고 e스포츠를 주류로 자 리 잡게 하려고 노력하는 연맹이나 조직들은 전통적인 스 포츠와 비슷해지기 위한 적법성과 일관성을 추구해왔다. 2015년에 카운터-스트라이크 게임의 프로 e스포츠선수 인 Kory Frieson은 자신과 동료들이 애더럴을 많이 쓴다 는 것을 인정하며, "우리 모두 애더럴을 복용하고 게임 중 이었다. 우리 대화(경기 중 주고받는 채팅)를 들었다면 분명 알았을 것이다”라고 말했다(Langley, 2016). Frieson의 깜짝 발언에 토너먼트를 주관했던 e스포츠 리 그(ESL)는 재빨리 반응하였다. 2015년 8월부터 ESL은 사이클 종목과 올림픽 정책에 기반한 약물금지 정책을 시 행하기 시작하였다(Wingfield \& Dougherty, 2015). 몇 몇 $\mathrm{e}$ 스포츠 연맹은 $\mathrm{ESL}$ 의 약물금지 정책 시행 이후 약물 테스트 프로토콜을 신설하였다. Frieson은 뉴욕 타임즈 와의 인터뷰에서 “절망감 때문에, 팀의 연패를 막기 위해 약을 먹었다"고 말했다. 애더럴 복용이 널리 퍼져있다고 Frieson이 밝히긴 했지만, 그 약 때문에 엘리트 e스포츠 선수가 되는 건 아니라고도 주장했다. Loland(2018) 또 한 취미로 자전거 타는 사람이 암페타민(적혈구 생성 촉 진제)을 복용한다고 해서 투르 드 프랑스에서 챔피언이 될 수는 있는 것이 아니듯이, 리탈린이나 애더럴 같은 약 물이 $\mathrm{e}$ 스포츠선수들의 주의력에 도움이 될 수 있을지언 정 그들에게 초능력을 주는 약으로 인식해서는 안 된다고 주장한다. $\mathrm{e}$ 스포츠의 약물복용 문제에 있어 또 다른 쟁점이 되는 것은 신경 향상 약물이 스포츠정신, 즉 스포츠의 본질을 훼손하느냐의 문제이다. 스포츠의 본질이 자연적인 신체 의 생리적 상태에서 발휘할 수 있는 최대의 능력을 정정 당당한 방법을 통해 경쟁하는 것이라면, 인간의 자연적인 상태에 어떤 인위적인 요소의 개입, 즉 약물의 사용은 스 포츠의 경쟁을 불공정한 것으로 만들어 스포츠의 본질을 해치는 행위이다(Lee \& Son, 2018). 신경 향상 약물을 이용하여 경쟁 상황에서 다른 선수를 앞서는 것은 열심히 노력하지 않고 손쉽게 얻어진 것이기에 일종의 속임수를 사용하는 것이고 근본적으로 경쟁을 불공정하게 만든다 는 것이다. 이러한 점에서 Lee와 Son(2018)은 타인을 수단이 아닌 목적으로 대우하라는 칸트의 정언명령에 근 거하여 스포츠에서 약물사용은 경쟁하는 상대방을 존중 하지 않는 반도덕적 행위이고, 상대를 이기는 목적의 수 단으로 대우하는 잘못된 행위라고 주장한다.

하지만 신경 향상 약물이 선수들의 훈련을 위한 노력 을 더욱 효과적이게끔 한다면, 즉 더 나은 성취를 가져오 게 한다면 그것은 노력과 분투를 개재한 것이므로 단순한 속임수로만 볼 수는 없다 $(\mathrm{Chu}, 2018)$. 몇몇의 스포츠철 학자들(Jones, 2015; Miah, 2004; Tännsjö, 2005; Tamburrini, 2005) 또한 인간은 본래 자기 증진이라는 욕구를 가진 존재이기에 자신의 신체적, 정신적 능력을 향상시키는 것이 타인에게 해를 끼치지 않는다면, 개인의 자율적 판단과 선택권을 존중해야 한다고 주장한다.

스포츠학자들(Jones, 2015; Loland, 2009; Schneider $\&$ Rupert, 2009)은 신경 향상 약물이 정상적인 인간이 라고 여겨지는 능력 이상을 가진 선수를 만들어냄으로써 비인간화를 초래하고 결국 인간이 하는 스포츠 본연의 정 신을 훼손할 것이라고 주장한다. 반면 자신에게 선천적으 로 주어진 것들을 새로운 의료기술을 활용하여 더 증진하 거나, 자신을 더욱 발전시키려는 개인의 선택과 판단을 비난해서는 안 된다는 입장도 있다(Tännsjö, 2005; Tamburrini, 200). 즉 “더 빠르게, 더 높이, 더 강하게”라 는 올림픽 모토를 실천할 수 있는 다양한 기술과 안전한 방 법이 있다면 그것을 활용하는 선수의 선택이 스포츠정신과 가치를 훼손한다고 할 수 없다는 주장이다. 이처럼 신경 향 상 약물이 과연 스포츠정신을 위협하는가의 문제도 $\mathrm{e}$ 스포 츠선수의 약물복용 문제에 있어 주요 쟁점이 되고 있다. 


\section{$\mathrm{e}$ 스포츠계의 바람직한 약물규제 방안}

$\mathrm{e}$ 스포츠 선수들은 사실 약물에 대해 잘 알고 있지 않다. 왜냐하면 약물복용에 대한 교육이나 약물 테스트가 e스포 츠계에는 거의 전무하기 때문이다. $\mathrm{e}$ 스포츠로서 최초로 시도된 도핑 테스트는 국제 $\mathrm{e}$ 스포츠연맹이 관할 단체로 참 가한 '2013 실내 무도 아시안게임’인데, 국제e스포츠연맹 이 세계반도핑기구(WADA)에 가입한 이후 처음으로 치 룬 $\mathrm{e}$ 스포츠 대회로서 시범 격으로 도핑테스트를 진행한 것이다(Lee, 2018.11.21). '2018 자카르타 팔렘방 아시 안게임'에서도 도핑테스트가 있었는데, e스포츠가 정식 스포츠로 인정받게 된 만큼 아시안게임 기준에 맞춰서 도 핑 검사를 받게 된 것이다(Lee, 2018.11.21). 하지만 라 이엇 게임즈나 블리자드와 같은 게임사에서 직접 주관하 는 유명 대회에선 도핑 테스트는 찾아보기 힘들다. 실제 로 세계 최고의 $\mathrm{e}$ 스포츠 대회라고 불리는 '리그 오브 레전 드 월드 챔피언십'은 물론, 세계 최초 연고지 기반 $\mathrm{e}$ 스포 츠 프로리그로 알려진 '오버워치 리그'에서는 도핑 테스트 는 실시되지 않는다(Lee, 2018.11.21).

$\mathrm{e}$ 스포츠 공정위원회 (Esports Integrity Commission, $\mathrm{ESIC)}$ 보고서 앞에는 ESIC 금지약물 목록이 기재되어 있는데, 이 목록에는 주의력, 각성, 집중력과 관련된 이유 로 흔히 처방되는 애더럴, 리탈린, 포칼린 등 일곱 가지 금지약물이 포함되어 있다(Holden, Kaburakis, \& Tweedie, 2019). 이러한 흔히 처방되는 약물을 금지하 는 것이 일으키는 문제점은 치료목적 사용면책 (TUE) 시 스템을 오용하거나, 집중력 향상 약물이 의학적으로 필요 한 선수들을 배제시킬 위험이 있다는 것이다. 이런 이유 때문에 ESIC의 약물금지 규정 시행에도 불구하고 이것 을 채택한 $\mathrm{e}$ 스포츠 리그는 거의 없다.

2017년 7\% 약간 넘는 것으로 추정되는 $\mathrm{ADHD}$ 의 세 계적 만연을 고려해볼 때, 세계 인구의 꽤 많은 인구가 치 료를 위해 메틸페니데이트나 애더럴 같은 처방약을 복용 하고 있음을 예상할 수 있다(Holden, Kaburakis, \& Tweedie, 2019). 흥미로운 것은 비디오 게임과 $\mathrm{ADHD}$ 간의 상관관계를 밝히는 많은 연구들이 있는데, 그 중 $\mathrm{ADHD}$ 치료법으로서 비디오 게임 소비가 줄 수 있는 이 로움에 관한 연구도 있다(Durkin, 2010; Wilkinson, Ang, \& Goh, 2008). e스포츠선수들 사이에 퍼진
$\mathrm{ADHD}$ 정도에 관한 포괄적 연구는 여전히 진행되고 있지 만, 비디오 게임에 드는 시간과 집중력 문제 간의 관련성 은 많은 연구에서 이미 언급되었다(Klass, 2011; Swing et al., 2010). Holden, Kaburakis와 Tweedie(2019) 에 따르면, 아마도 꽤 많은 e스포츠선수들이 경쟁에서 이 득을 얻기 위해 의학적으로 필요 없음에도 처방약을 복용 하고 있다. 그러나 비록 일부 복용이 의학적으로 승인받 지 않은 것일지라도, 그 약들을 복용하는데 충분한 의학 적 필요성이 있을 수 있고, 이러다 보면 치료목적 사용면 책 (TUE)을 통해 약물복용을 승인해주는 것이 약물복용 금지 정책을 완전히 무력화시킬 수 있다. 대안이 있다면 기존 스포츠의 약물정책을 그대로 베껴 적용하는 것보다 $\mathrm{e}$ 스포츠의 환경적 특성을 고려하여 $\mathrm{e}$ 스포츠에만 적용되 는 해결책을 강구하는 것이다. 즉 $\mathrm{WADA}$ 가 제시하는 세 가지 조건, 건강(health), 향상 (enhancement), 스포츠 정신(sporting spirit)을 일괄적으로 적용하기보다 $\mathrm{e}$ 스 포츠의 경우처럼 이로움이 유해한 효과를 능가하면 특정 약물을 허용할 수도 있을 것이다. $\mathrm{e}$ 스포츠와 기존 전통적 스포츠간의 비교가 지속적으로 이뤄지고 있지만, $\mathrm{e}$ 스포 츠가 다른 관리 방식과 제도를 택함으로써 이익을 얻는 부분들도 있다. 약물 정책 역시 $\mathrm{e}$ 스포츠가 새롭게 어떤 정책의 효과를 시험해보는 수단이 될 수 있을 것이다.

\section{결론}

$\mathrm{e}$ 스포츠 산업의 인기와 성장과 더불어 $\mathrm{e}$ 스포츠선수들 의 경기력 향상 약물복용 문제는 e스포츠계가 피할 수 없 는 윤리적 문제로 부상하였다. 의료과학의 발달로 인해 뇌 기능을 증진시키는 약물은 상대적으로 새로운 사안인 동시에 두뇌 스포츠라고 불리는 $\mathrm{e}$ 스포츠계에 미치는 파 장이 크기에 이 문제에 대해 매우 신중하게 접근할 필요 가 있다. 이에 본고는 $\mathrm{e}$ 스포츠선수들의 약물복용 문제는 기존 전통적 스포츠에서의 약물복용 문제와 어떤 다른 윤 리적 쟁점이 있는지를 고찰하고, 이러한 약물복용 문제에 대응하기 위한 $\mathrm{e}$ 스포츠계의 바람직한 방안을 모색하고자 하였다.

$\mathrm{e}$ 스포츠 단체는 독특한 균형을 잡아야할 처지에 있다. $\mathrm{e}$ 스포츠가 아시아, 미국, 유럽 등 전 세계적으로 점점 더 
인기 있어지는 한, 제도와 관리체제를 기존 스포츠 모델 에 맞추려는 노력 역시 계속될 것이다. 그런 차원에서 $\mathrm{WADA}$ 가 제시하는 약물복용에 관한 세 가지 기준을 고 수해오고 있지만, 안전하게 치료제로 처방되지만 승인되 지 않는 인지 향상 약물복용의 잠재적 해로움 역시 고려 하는 정책을 수립하는 데는 거의 손을 놓고 있다. 이미 많 은 e스포츠선수들이 허가, 무허가를 막론하고, 건강상의 목적이든 뇌 기능 촉진의 목적이든 신경 향상 약물을 널 리 사용하고 있다. 의학기술의 발달로 점점 높아지는 약 물의 안전성, 개인의 자율성을 점점 더 중요시하는 사회 적 풍토, 경쟁을 더욱 고도화 시키는 가운데 변해가는 스 포츠정신의 개념을 고려해 볼 때, $\mathrm{e}$ 스포츠선수의 약물복 용을 금지하는 현재의 정책과 규정은 힘을 잃어갈 가능성 이 상당히 크다. 본 논문이 제안하는 것은 $\mathrm{e}$ 스포츠선수의 약물복용을 널리 승인해주자는 것이 아니다. 본고가 주장 하는 바는, 약물복용에서 오는 이로움과 해로움의 균형을 잘 맞춰 $\mathrm{e}$ 스포츠가 가진 가치의 구현을 최대화 할 수 있는 정책과 규정을 수립해야 한다는 것이다. $\mathrm{e}$ 스포츠 공정위 원회(ESIC)의 정책이나 $\mathrm{WADA}$ 의 금지 목록은 $\mathrm{e}$ 스포츠 선수의 수요에는 맞지 않을 것이며 새로운 문화로서 $\mathrm{e}$ 스 포츠 산업의 성장을 방해할 위험마저 있다. 현재 e스포츠 계가 취하고 있는 약물복용 금지정책은 치료목적 사용면 책(TUE) 시스템을 남용하거나 합법적으로 약을 필요로 하는 많은 선수들을 배제시킬 가능성이 크다.

비디오 게임이 $\mathrm{ADD} / \mathrm{ADHD}$ 증상을 가진 이들에게 줄 수 있는 잠재적 이로움과 비디오 게임 사용 간의 의학적 관계는 계속 연구되어야 한다. 의학적으로도 이롭고 폭넓 게 사용되고 있는 약물을 지나치게 규제하는 정책은 프로 $\mathrm{e}$ 스포츠선수들 뿐 아니라 아마추어 선수들의 참여율에도 부정적인 영향을 끼칠 수 있다. 이에 완화된 약물 규제 정 책이 필요하지만, 이 정책은 치료목적 사용면책(TUE)의 효용성과 접근성에 관한 교육의 확대와 더불어 이루어져 야 한다. 지나치게 규제하는 정책은, 치료목적 사용면책 (TUE)을 얻을 수 있을 것인지에 대한 걱정 때문에 미래 게이머들을 위축시킴으로써 $\mathrm{e}$ 스포츠의 지지기반을 무너 뜨릴 수도 있다. 그러므로 e스포츠의 환경적 특성을 고려 한 e스포츠선수들에게 합리적으로 적용될 수 있는 약물 복용 관련 지침을 마련하는 일이 중요하다. 또한 e스포츠 선수들의 윤리의식과 판단능력을 증진시키기 위한 의무
적인 교육도 병행되어야 한다. 도핑이 무엇인지에 대해 명확하게 배우는 것만으로도 응급 처치가 될 수 있다. 즉, 약물복용이 야기하는 윤리적 문제들이 무엇인지에 대해 $\mathrm{e}$ 스포츠선수들이 명확히 이해하고 스스로가 올바른 선택 과 판단을 내릴 수 있도록 도덕적 자율성을 길러주는 교 육이 무엇보다 필요하다. 처벌과 규제에만 치중하는 단기 적인 대응보다는 예방과 교육에 중점을 두는 제도나 정책이 약물복용 문제를 근본적으로 해결하는 방안이 될 것이다.

\section{참고문헌}

Abanazir, C. (2019). Institutionalisation in E-Sports. Sport, Ethics and Philosophy, 13(2), 117-131.

Brown, W. (2009). The Case for Perfection. Journal of the Philosophy of Sport, 36(2), 127-139.

Chrysopoulos, P. (2016.08.12). Doping in Ancient Greece Olympic Games. Greek Reporter. Retrieved on March 12, 2020 from https://greece.greekreporter.com/2016/08/12/ doping-in-ancient-greece-olympic-games/

Chu, B. W. (2014). The Legitimacy of Moral Education in an Age of Pharmacological Neuroenhancement. Journal of Moral \& Ethics Education, 43, 47-71.

Chu, B. W. (2018). The Pros and Cons of Pharmacological Cognitive Enhancement. Journal of Moral \& Ethics Education, 59, 105-127.

Creswell, J. (2007). Qualitative Inquiry and Reserch Design: Choosing among Five Approaches (2nd ed.). Thousand Oaks, CA: Sage.

Durkin, K. (2010). Videogames and Young People with Development Disorders. Review of General Psychology, 14(2). 122-140.

Engelberg, T., \& Skinner, J. (2016). Doping in Sport: Whose problem is it? Sport Management Review, 19(1), 1-5.

Feezell, R. (2013). Sport, Philosophy and Good Lives. Lincoln, NE: University of Nebraska Press.

Hemphill, D. (2005). Cybersport. Journal of the Philosophy of Sport, 32, 195-207.

Holden, J., \& Ehrlich, S. (2017). Esports, Skins Betting, and Wire Fraud Vulnerability: Gaming, Doping, and Global Governance. Maryland Journal of International Law, 32(1), 236-273. 
Holden, J., Kaburakis, A., \& Rodenberg, R. (2017). The Future Is Now: eSports Policy Considerations and Potential Litigation. Journal of Legal Aspects of Sport, 27(1), 46-78.

Holden, J., Kaburakis, A., \& Tweedie, J. (2019). Virtue(al) Games: Real Drugs. Sport, Ethics and Philosophy, 13(1), 19-32.

Jang, G. R. (2020.03.09). 돈 되는 ‘ $e$ 스포츠' 시장, 판 커진다. Newsway. Retrieved on March 23, 2020 from http://www. newsway.co.kr/news/view?tp=1\&ud=20200309141613912 26.

Jenny, S., Manning, R., Keiper, M., \& Olrich, T. (2017). Virtual(ly) Athletes: Where eSports Fit Within the Definition of "Sport" Quest, 69(1), 1-18.

Jones, C. (2015). Doping as Addiction: Disorder and Moral Responsibility. Journal of the Philosophy of Sport, 42(2), 251-267.

Kim, D. C. (2017). Ethical Issues and Moral Educational Meaning of Human Enhancement. Journal of Ethics Education Studies, 44, 25-58.

Kim, H. J. (2014.12.22). [인사이드MLB] 크리스 데이비스 기묘 한 약물 논란. Naversports. Retrieved on February 24, 2020 from https://sports.news.naver.com/news.nhn?oid= 224\&aid $=0000003348$.

Kim, H. Y. (2020.03.06). 2020년 e 스포츠 수익1조 돌파 예상... 스폰서십-중계권 증가. Dailyesports. Retrieved on March 3, 2020 from http://www.dailyesports.com/view. php?ud=202003051404089801283f60ce7c_27.

Kim, J. M. (2019.08.17). 이대호 선수보다 많이번다... 연봉30억 '페어커' 되고 싶다면. Joongangilbo. Retrieved on February 26, 2020 from https://news.joins.com/article/235 54357.

Kim, M. G. (2019.10.11). SKT-美 컴캐스트 글로벌 $e$ 스포츠전문 기업 ‘ $T 1$ ' 합작설립. Joynews24. Retrieved on March 2, 2020 from http://www.inews24.com/view/1214141.

Kim, M. J. (2018). Pharmaceutical Cognitive Enhancement in Zero-Sum Society and Justice. Journal of the New Korean Philosophical Association, 94, 419-437.

Klass, P. (2011.05.09). Fixated by Screens, but Seemingly Nothing else. NewYorkTimes. Retrieved on March 8, 2020 from https://www.nytimes.com/2011/05/10/health/views/ 10klass.html

Langley, H. (2016.04.01). Sex, Drugs and Counter-strike: eSports is fighting its demons. Techradar. Retrieved on March 22, 2020 from https://www.techradar.com/news/ gaming/sex-drugs-and-counter-strike-esports-is-fightingits-demons-1318109

Lee, H. W. (2019.06.29). 서울대 의대 입학보다 프로게이머 되 기 더 어려워. Chosunilbo. Retrieved on March 6, 2020 from http://news.chosun.com/site/data/html_dir/2019/06/ 28/2019062801980.html.

Lee, J. H. (2018.11.21). $e$ 스포츠도 ‘도핑 테스트’ 시스템 갖춰야 할 때. GameMeca. Retrieved on April 1, 2020 from https://www.gamemeca.com/view.php?gid=1508924.

Lee, J. H. (2020.03.12). Unfair Contract of eSports. Korea GQ. Retrieved March 24, 2020 from http://www.gqkorea.co.kr /2020/03/12/e\%EC\%8A\%A4\%ED\%8F\%AC\%EC\%B8\%A0 \%ЕC\%9D\%98-\%ЕВ\%B6\%88\%ЕА\%В3\%B5\%ЕС\%А0\%95 -\%ЕА\%В3\%84\%ЕС\%95\%BD/.

Lee, J. S., \& Shon, J. H. (2018). Ethical Approach on Performance Enhancement Drugs in Athlete. Korean Journal of Sports Science, 27(5), 21-30.

Lee, S. M., \& Choi, J. H. (2013). The Ethical Debate on Cognitive Enhancement. Korean Journal of Medical Ethics, 16(2), 231-248.

Lim, J. H. (2019.10.02). $e$ 스포츠, ‘스포츠 의학’ 통한 집중 관리 필요해졌다. OSEN. Retrieved on April 12, 2020 from http://osen.mt.co.kr/article/G1111233370.

Llorens, M. R. (2017). eSport Gaming: The Rise of a New Sports Practice. Sport, Ethics and Philosophy, 11(4), 464-476.

Loland, S. (2002). Fair Play in Sport: A Moral Norm System (3th ed). London \& New York: Routledge.

Loland, S. (2009). The ethics of performance-enhancing technology in sport. Journal of the Philosophy of Sport, 36, 152-161.

Loland, S. (2018). Performance-enhancing drugs, sports, and the ideal of natural athletic performance. The American Journal of Bioethics, 18(6), 8-15.

Maher, B. (2008). Poll Results: Look Who’s Doping. Nature, 452, 674-676.

Miah, A. (2004). Genetically modified athletes: biomedical ethics, gene doping and sport. New York: Routledge.

Min, T. W. (2018.04.10). $A D H D$, 사춘기 반항. 중2병쯤으로 방치 땐 평생 고생. Kukminilbo. Retrieved on March 19, 2020 from http://news.kmib.co.kr/article/view.asp?arcid= 0923930407\& $\&$ code $=14130000 \& \mathrm{cp}=$ nv .

No, J. W. (2019.12.05). [e스포츠 인생2막](1)게임 프로화 20 년...“은퇴 이후 설계 필요할 때” Edaily. Retrieved on 
March 2, 2020 from https://www.edaily.co.kr/news/read? newsId $=03844166622715568 \&$ mediaCodeNo=257\&OutLnk $\mathrm{Chk}=\mathrm{Y}$.

Overbye, M., \& Wagner, U. (2013). Between Medical Treatment and Performance Enhancement: An Investigation of How Elite Athletes Experience Therapeutic Use Exemptions. International Journal of Drug Policy, 24(6), 579-588.

Paek, C. (2017.12.26). 대기업은 왜 $e$ 스포츠 철수하나? Jugankyunghyang. Retroeved on March 9, 2020 from http://weekly.khan.co.kr/khnm.html?mode=view\&code=115 \&artid=201712191701351\&pt=nv

Park, G. L. (2019.10.01). 홍정욱 딸이 가져온 애더럴..."머리 좋 아지는 약? 득보다 실". YTN. Retrieved on March 24, 2020 from https://www.ytn.co.kr/_ln/0103_201910011259 323509.

Parry, J. (2019). E-sports are Not Sports. Sport, Ethics and Philosophy, 13(1), 3-18.

Racine, E., \& Forlini, C. (2010). Cognitive Enhancement, Lifestyle Choice or Misuse of Prescription Drugs? Neuroethics, 3(1), $1-4$.

Rasmussen, N. (2008). America's First Amphetamine Epidemic 1929-1971: AQuantitative and Qualitative Retrospective with Implications for the Present. American Journal of Public Health, 98(6), 974-985.

Rietkert, R. (2020.01.07). Newzoo's Esports Trends to Watch in 2020. Retrieved on March 23, 2020 from https://newzoo.com/ insights/articles/newzoos-esports-trends-to-watch-in-2020/

Schneider, A., \& Rupert, J. (2009). Constructing winners: the science and ethics of genetically manipulating athletes. Journal of the Philosophy of Sport, 36, 182-206.

Suits, B. (2018). The Elements of Sport. In W. Morgan (Ed.), Ethics in Sport (3rd Ed.) (pp. 33-44). Champaign, IL: Human Kinetics.
Swing, E., Gentile, D., Anderson, C., \& Walsh, D. (2010). Television and Video Game Exposure and the Development of Attention Problems. Pediatrics, 126(2), 214-221.

Tamburrini, C. (2005). Educational or genetic blueprints, what's the difference? In C. Tamburrini \& T. Tännsjö (Eds.), Genetic technology and sport: ethical questions (pp. 82-90). London; New York: Routledge.

Tännsjö, T. (2005). Genetic engineering and elitism in sport. In C. Tamburrini \& T. Tännsjö (Eds.), Genetic technology and sport: ethical questions (pp. 57-69). London; New York: Routledge.

Tcholl, P., \& Dvorak, J. (2012). Abuse of Medication During International Fooball Competition in 2010: Lesson Not Learned. British Journal Sports Medicine, 46(16), 1140-1141.

Wilkinso, N., Ang, R., \& Goh, D. (2008). Online Video Games Therapy for Mental Health Concerns: A Review. International Journal of Social Psychiatry, 54(4), 370-382.

Wingfield, N. (2014.08.30). In eSports, Video Gamers Draw Real Crowds and Big Money. NewYorkTimes. Retrieved on January 12, 2020 from https://www.nytimes.com/2014/ 08/31/technology/esports-explosion-brings-opportunity-riche s-for-video-gamers.html

Wingfield, N., \& Dougherty, C. (2015.07.23). Drug Testing Is Coming to E-Sports. The New York Times. Retrieved on March 3, 2020 from https://www.nytimes.com/2015/07 /24/technology/drug-testing-is-coming-to-e-gaming.html Yang, H. J. (2015.09.04). 행복일까 혼란일까, 성큼 다가온 ‘ 스마 트 알약' Hankookilbo. Retrieved on March 26, 2020 from https://www.hankookilbo.com/News/Read/20150904 1294308651.

Yesalis, C., \& Bahrke, M. (2002). History of Doping in Sport. International Sports Studies, 24(1), 42-76. 


\title{
$\mathrm{e}$ 스포츠선수의 약물복용 문제에 관한 윤리적 고찰
}

\author{
박성주 ${ }^{1}$, 임다연 ${ }^{2}$, 김진희 ${ }^{3}$ \\ 국민대학교, 교수 \\ ${ }^{2}$ 국민대학교, 강사 \\ ${ }^{3}$ 안동대학교, 교수
}

〔목적〕현재 $\mathrm{e}$ 스포츠는 엄청난 인기를 구가하고 있고 $\mathrm{e}$ 스포츠에 관한 학계의 관심과 연구도 활발해지고 있 다. 하지만 현재 $\mathrm{e}$ 스포츠에 대한 학계의 연구는 $\mathrm{e}$ 스포츠가 정말 스포츠인지, 즉 스포츠로서 갖는 자질과 지위 에 관한 논의에 집중되어 있고 $\mathrm{e}$ 스포츠에서 발생하는 여러 윤리적 문제에 관한 학술적 조사나 연구는 거의 없는 실정이다. 이러한 학문적 공백을 메꾸기 위해 본 연구는 e스포츠가 직면한 인지 향상 약물(cognitive enhancement drugs) 복용문제의 윤리적 쟁점을 분석함으로써 e스포츠계의 약물복용 문제 해결을 위한 바 람직한 방향성을 제시하고자 한다. 〔방법) 이러한 연구의 목적을 달성하기 위해, 먼저 e스포츠의 환경적 특징 을 살펴봄으로써 $\mathrm{e}$ 스포츠계 부정행위의 양상과 선수들이 약물복용 문제에 노출되는 배경을 파악하였다. 다음 으로 e스포츠선수의 인지 향상 약물 복용문제에 관해 어떤 윤리적 쟁점이 존재하고, 왜 그것이 쟁점이 되는지 를 여러 학자들의 입장을 통해 고찰하였다. 끝으로 $\mathrm{e}$ 스포츠의 환경적 특성을 고려할 때 전통적 스포츠로부터 차용한 약물복용 금지 정책이 왜 $\mathrm{e}$ 스포츠에 부적합한지를 지적하며, 약물복용 문제에 대처하기 위한 $\mathrm{e}$ 스포츠 계의 바람직한 접근방안을 제시하였다.〔결과〕 e스포츠 공정위원회(ESIC)의 정책이나 세계반도핑기구 (WADA)의 금지목록은 e스포츠선수의 수요에는 맞지 않을 것이며 새로운 문화로서 e스포츠 산업의 성장을 방해할 위험마저 있다. $\mathrm{e}$ 스포츠의 환경적 특성을 고려한 $\mathrm{e}$ 스포츠선수들에게 합리적으로 적용될 수 있는 약물 복용 관련 지침을 마련하는 일이 중요하며 약물복용 문제에 대한 $\mathrm{e}$ 스포츠선수들의 윤리의식과 판단능력을 증 진시키기 위한 의무적인 예방교육이 실시되어야 한다. ‘결론) $\mathrm{e}$ 스포츠가 주로 젊은 층을 대상으로 세계적으로 인기를 끌고 있고, 그로 인해 프로 $\mathrm{e}$ 스포츠 선수의 위상과 지위도 높아지면서 청소년에게 미치는 파급력과 영 향력을 감안할 때, $\mathrm{e}$ 스포츠의 윤리적 문제, 특히 약물복용에 관한 문제는 시급하고 시의적인 논의이며 $\mathrm{e}$ 스포츠 의 확산과 건강한 발전에도 함의하는 바가 크다.

주요어: e스포츠, 인지향샹약물, 부정행위, 윤리적 쟁점, 세계반도핑기구 